\title{
VERBAL PREFIXES AND SUFFIXES IN NOMINALIZATION：GRAMMATICAL RESTRICTIONS AND CORPUS DATA
}

\author{
ANNA PAZELSKAYA \\ Independent researcher, Moscow
}

\section{A B S T RAC T}

This paper aims to investigate the options of -nie/tie nominalization chosen by various verbal stems in Russian, as far as these options can be seen in the texts of the Russian National Corpus. The paper is in some sense an addition to Sergei Tatevosov's work presented in Tatevosov (2009) in that it is an attempt to look beyond the grammatical restrictions outlined in this work.

\section{[1] GRAMMAR OF THE -NIE/TIE NOMINALIZATION}

Russian verbs all bear perfective or imperfective aspect, depending on their lexical properties and on the suffixes and prefixes in the stem, and many Russian verbs have a corresponding -nie(-tie) nominalization.

\begin{tabular}{llll}
\hline & basic “imperfective" & prefixed “perfective” & $\begin{array}{l}\text { prefixed and suffixed } \\
\text { "imperfective" }\end{array}$ \\
\hline Verb & PISA-t' 'to write' & $\begin{array}{l}\text { O-pisa-t' } \\
\text { 'to describe' }\end{array}$ & $\begin{array}{l}\text { o-pis-YVA-t' } \\
\text { 'to describe, } \\
\text { to be describing' } \\
\text { o-pis-YVA-nie } \\
\text { 'describing' }\end{array}$ \\
& & $\begin{array}{l}\text { O-pisa-nie } \\
\text { 'description'/ } \\
\text { ?'describing' }\end{array}$ & \\
\hline
\end{tabular}

TABLE 1: -nie(-tie) nominalization, prefixes and suffixes of a verbal stem. ${ }^{1}$

For instance, as shown in Table 1, the basic imperfective verb pisa-t' 'to write' has a corresponding -nie/tie nominal pisa-nie 'writing'. This basic imperfective

[1] Note that the words "verbal stem", "nominalization" and "verbal prefixes \& suffixes" are used here only since they provide a convenient way of naming the things involved; as shown in Pazelskaya \& Tatevosov (2006), it is more appropriate to speak about a non-specified initial stem acquiring verbal/nominal features in the course of derivation, and at least some of the Aktionsart morphemes attach to this underspecified stem earlier than it becomes a verb or a nominal. 
verb can be prefixed with $o$ - to give a perfective 0 -pisa- $t$ ' 'to describe', and this prefixed perfective verb also has a nominal -nie/tie counterpart 0-pisa-nie referring to the concept 'description' or, less likely, the 'process of describing'. This prefixed verb can, in turn, be further augmented with the suffix -yva- to give a socalled "secondary imperfective" o-pis-YVA-t' 'to describe, to be describing' with its own nominalization o-pis-YVA-nie 'process of describing'.

Despite this formal parallelism, nominals with Aktionsart prefixes and -yvaare crucially different from their corresponding verbs. In verbs these derivational morphemes are primarily responsible for the change of verbal aspect (from imperfective to perfective and back to imperfective, see e.g. Forsyth (1970), BabkoMalaya (1999), Dickey (2000), Zaliznjak \& Shmelev (2000). This change induces several well-known effects, most known of which are the ban on perfective verbs as the infinitival complement of phase verbs (cf. (1-a, b), see e.g. Borik 2006), and aspectual composition (cf. (2-a, b), see Filip 1999, 2005a,b).
a. Vasja nača-l pisa-t' pis'mo
Vasja start-PST write-INF letter
'Vasja started writing a letter.'
b. 'Vasja nača-l NA-pisa-t' pis'mo
Vasja start-PST PREF-write-INF letter
Int.: 'Vasja started writing a letter.'

(2) a. Vasja pisa-1 pis'm-a (dva časa) ( ${ }^{\mathrm{OK}}$ no ostalos' napisa-t' ešče Vasja write-PST letter-PL two hours but remain write-INF still mnogo pisem)

many letters

'Vasja has been writing letters for two hours ( ${ }^{\mathrm{OK}}$ but there still remain many letters to write).'

b. Vasja NA-pisa-l pis'm-a (za dva časa) ('no ostalos' napisa-t' Vasja PREF-write-PST letter-PL in two hours but remain write-INF ešč mnogo pisem)

still many letters

'Vasja has written the letters in two hours (*but there still remain many letters to write).'

The only formal difference between sentences (2-a) and (2-b) is the presence of the prefix $n a$ - on the verb in the latter. However, at the level of meaning the difference is crucial. The first sentence is atelic (and therefore it is consistent with $d v a$ časa 'for two hours' adverbial) with a cumulative interpretation of the internal incremental argument pis'ma 'letters' (so that a continuation assuming the writing of additional letters is possible). The second sentence is telic (as shown by the adverbial za dva časa 'in two hours'), and pis'ma the NP 'the letters' re- 
ceives a unique maximal interpretation (see Filip 2005a), the NP referring to a contextually-specified set of letters which were all written during the described event. Thus, with a prefixed verb the reference of both the situation and the internal incremental argument becomes quantized, and not cumulative like in the case of an unprefixed verb.

However, the same two effects of perfectivity are completely absent in deverbal nominals corresponding to perfective verbs. First, both unprefixed and prefixed nominals can occur in the context of phase verbs $(3-a, b)$.
a. Vasja nača-l pisa-nie pis'm-a
Vasja start-PST write-NMN letter-GEN
'Vasja started writing a letter.'
b. OK Vasja nača-l NA-pisa-nie pis'm-a
Vasja start-PST PREF-write-NMN letter-GEN
'Vasja started writing a letter.'

Second, -nie/tie nominals show aspectual composition of the "English" type, when the cumulativity/quantizedness of a situation referred to by a verb is determined by the cumulativity/quantizedness of the internal incremental argument, and not by the properties of the verb itself.

a. Vasja včera zanima-l-sja pisa-ni-em pis-em Vasja yesterday be.busy-PST-REFL write-NMN-INSTR letter-GEN.PL /NA-pisa-ni-em pis-em /PREF-write-NMN-INSTR letter-GEN.PL Context: What has Vasja been doing yesterday? 'Yesterday Vasja was busy writing letters.'
b.
Pisa-nie /NA-pisa-nie pis-em zanja-l-o u
write-NMN /PREF-write-NMN letter-GEN.PL take.PST-N at
Vas-i dva časa ('no ostalos' napisa-t' ešče mnogo pisem)
Vasja-GEN two hours but remain write-INF still many letters
Context: Vasja is involved in a lawsuit and yesterday he had to write ten letters to the other participants of the suit
'Writing the letters took Vasja two hours (*but there still remained many letters to be written).'

In (4-a), as well as in (4-b), both "imperfective" (without the prefix na) and "perfective' (with the prefix) nominals are equally grammatical. Moreover, the interpretation of the whole sentence, as well as the cumulativity/quantizedness of the NP (na-)pisa-nie pisem 'writing (the) letters' does not depend on the choice of the nominal. Both NPs (na )pisa-nie pisem in the first sentence are cumulative, given cumulative reference of pisem 'letters', while in the second sentence, with the 
context-specified and therefore quantized set of letters to be written, the same NPs are quantized.

These two crucial differences in aspect-induced behaviour between prefixed/ unprefixed verbs, on the one side, and prefixed/unprefixed nominals, on the other side, leads to a conclusion that Aktionsart prefixes and -yva- are not directly responsible for the effects of aspect in Russian. Rather, Aktionsart prefixes and -yva- in nominals (and, consequently, in verbs, if we stick to the hypothesis that verbs and -nie/tie nominals are formed from the same stems) are event structure modifiers (Tatevosov 2003; Pazelskaya \& Tatevosov 2006; Tatevosov 2009) rather than aspectual ones, and therefore -nie/tie nominals in Russian do not bear aspect (contrary to Ivannikova (1972), but in line with Peshkovsky (1956); Comrie $(1980))^{2}$.

NOTE ON TERMINOLOGY. Although the notions of perfectivity and imperfectivity are inapplicable to verbal stems without inflection and, especially, to nominalizations, for convenience I will use the terms "perfective/imperfective stem" and "perfective/imperfective nominal" to refer to 'a stem which gives rise to a perfective/resp. imperfective verb' and to 'a nominal derived from such a stem'. Imperfective stems include basic stems referring to processes and activities, and perfective stems suffixed with -yva- or - $a$-. Perfective stems are (at least synchronically) basic perfective stems and prefixed stems.

However, not every prefixed/suffixed verb has a corresponding -nie/tie nominal. The picture presented in Table 1 above where every new derived verbal stem gives rise to a grammatical -nie/tie nominalization is relatively rare. There are two types of restrictions on the occurrence of Aktionsart morphemes in nominals: absolute (grammatical) restrictions and individual, lexicalized ones, which are more accidental in nature. The grammatical restrictions (according to Pazelskaya \& Tatevosov 2008; Tatevosov 2009) are the following

- Process deverbal nouns in Russian maximally contain a projection of the "secondary imperfective" morpheme -yva-.

- Any material that merges outside -yva-blocks nominalization.

E.g., external prefixes (see Ramchand (2004), cf. superlexical prefixes in Romanova $(2004,2006))$ merged outside -yva- are impossible in nominalizations (5,

[2] Moreover, other types of deverbal nominals in Russian do not bear aspect either, although nominals derived via different models show a number of distinctions in their syntax and morphology, see Pazelskaya (2009a,b). Cf. also observations on various distinctions of aspectual nature in English deverbal nominals (Brinton 1995) and their French counterparts (Martin 2008). 
6-a), while prefixes merged lower are generally fine (6-b). One and the same prefix can have more than one landing site, and it only blocks nominalization when it attaches above -yva- (6-a), not below (6-b):

PO-side-t' $\quad$ - *po-side-nie

DELIM-sit-INF DELIM-sit-NMN

'to sit for some time'

(6) a. [na-[[otkry-]va]]-t' banok $-{ }^{*}$ naotkryvanie banok

CUMUL-open-YVA-INF cans

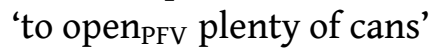

b. [[na-[dar-]]iva]-t' podarkov - nadarivanie podarkov

CUMUL-give-YVA-INF presents

'to regularly give $\mathrm{IPFV}_{\mathrm{P}}$ plenty of presents'

The order of attaching of the prefix and -yva-in verbal stems, marked by square brackets in $(6-a, b)$, is unambiguously justified by the aspect of the resulting verb: if the ("perfectivizing") prefix is merged after the ("imperfectivizing") suffix, the verb as a whole will be perfective, as in (6-a), and if the suffix is structurally above the prefix, the verb will be imperfective, as in (6-b). Only in the second case is the nominalization possible, since in the first case it would require to nominalize a stem containing more than the $-y v a-$ projection, namely, the projection of the perfectivizing prefix attached above -yva-.

This constraint on the order of attachment is the only strict one. Other restrictions are irregular and seem to be related to individual properties of a given stem (i.e. lexical). In many cases only one member of an "aspectual pair" can be nominalized with -nie/tie, the other being completely out (7-a), less frequent (7-b), or referring to a different meaning of the same verb (7-c).
a. da-t' 'to give $\mathrm{PFV}$ ' $-*$ da-tie $d a-V A-t$ 'to give $\mathrm{IPFV}$ ' ${ }^{\mathrm{OK}} d a-V A-n i e$ 'giving'
b. pozna-t' 'to get $t_{\mathrm{PFV}}$ to know, to cognize $\mathrm{PFV}$ - pozna-nie 'cognition' pozna-VA-t' 'to cognize $\mathrm{IPFV}$ - ?? pozna-VA-nie 'cognition'
c. otkry- $t$ ' 'to open $\mathrm{PFV}$ (a door), to discover $\mathrm{PFV}_{\mathrm{PF}}$ (America)' - otkry-tie 'dis- covery (of America)'

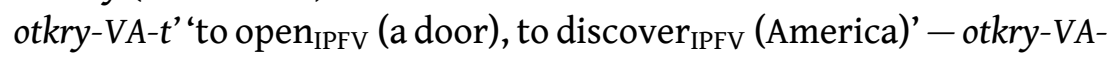 nie 'opening ((of) the door)'

The examples in (7) are restricted to aspectual pairs where the imperfective stem is formed by secondary imperfectivization, i.e. -yva- suffixation, of the unprefixed stem, but they show the range of available options. The differences in acceptability and meaning of nominalizations of different stems cannot be (at least so it seems by looking at the data) attributed to any difference between suffixed and 
unsuffixed stems as such. There are verbal stems very close to those in (7) with different behaviour under nominalization, cf. (7-a) to (8-a), (7-b) to (8-b), and (7-c) to $(8-c)$.
a. vzja-t' 'to take $\mathrm{PFV}$ ' ${ }^{\mathrm{OK}}$ vzja-tie

 - ${ }^{\mathrm{OK}}$ uzna-VA-nie 'recognition'
c. pokry-t' 'to cover ${ }_{\mathrm{PFV}}$ ' - pokry-tie 'covering' pokry-VA-t' 'to cover ${ }_{\mathrm{IPFV}}$ ' - pokry-VA-nie 'covering'

The basic hypothesis is, therefore, that the occurrence of Aktionsart morphemes merged below $-y v a-$ and of $-y v a$ - itself in nominalizations is not restricted by grammatical rules. What we see in (7) and (8) are preferences and tendencies, sometimes suggesting pragmatic or euphonical factors to be responsible for the distribution, and sometimes we are just faced with lexicalized properties of the stems.

The analysis of statistical preferences, tendencies, lexicalized properties is exactly where text corpora can prove useful, so what if we take corpus data into account and try to look beyond the grammar?

Questions addressed in this paper are:

- What are the distributions of the nominalization patterns with respect to Aktionsart morphemes of the stem?

- Are there types of stems which give rise to more nominalizations than other types of stems?

- Are there types of stems which give rise to more frequently used nominalizations?

- Is there any relation between frequency distributions of nominals and verbs sharing the same stems?

- What are the possible reasons for these distributions?

\section{[2] DATA SAMPLES}

This research and all the calculations in it are based on the annotated part of the Russian National Corpus (www . ruscorpora.ru) containing 557555 sentences and 6179022 words. In what follows, I will refer to it just as the Corpus for convenience. In order to choose the most frequent verbs/nominals for the investigation, I also used a word frequency list for the Corpus, i.e. a list of lemmatized words in which every word has a score corresponding to the number of occurrences of this word in the Corpus. 
This Corpus was used to form two research samples of nominalizations, based on different principles: Sample 1 "from verb to nominalization", and Sample 2 "nominalizations as they are". In both cases I chose only event nominalizations, i.e. deverbal nominals referring to more or less the same situations as the one denoted by the corresponding verb, excluding result, manner, agent etc. (cf. Padučeva 1974; Grimshaw 1990; Alexiadou 2001, for further discussion of these types of nominals).

Sample 1, based on the "from verb to nominalization" principle, was compiled as follows. I collected the top verbs in the frequency list in the current Corpus and broadened the sample with the derivational nests of these verbs (for basic verbs I added their prefix derivatives, for other verbs the basic verbs they were derived from and the derivatives). This resulted in 201 verbs (98 "seeding" verbs + their derivates and/or basic verbs they are derived from). These verbs gave rise to 136 nominals (see section [3.1] for details).

Sample 2 includes the 209 most frequent -nie/tie nominals, so it shows just -nie/tie nominalizations as they are.

Sample 1 is needed to be able to compare the scores attested for nominals with those for verbs, while Sample 2 presents more balanced and natural results for the nominals themselves.

This research is centered around two main parameters: the number of nominals corresponding to a certain type of stem and the average frequency of the nominals of a certain type in the Corpus. Average frequency is the average of the frequencies of all the words of a group in the Corpus, i.e. the average of the numbers of occurrences of the word among all the words in the Corpus.

\section{[3] CORPUS STUDY}

Let us first see the results for the two samples ("verb-based" sample and "nominalbased" sample) separately and then compare them.

\section{[3.1] Sample 1. Most frequent verbs and their nominalizations}

Let us start from the "from verb to nominalization" sample. Figure 1 shows how the set of the verbs for future nominalization has been chosen. Each of 98 "seeding" verbs from the top of the frequency word list was taken to form a maximum of derivations from those shown in the scheme.

Not all the verbs allow for all the derivations, and not every stem can be nominalized. Therefore, these operations resulted in a set of a total of 201 verbs, of which 95 were perfective and 106 imperfective, giving rise to 136 nominals, 48 


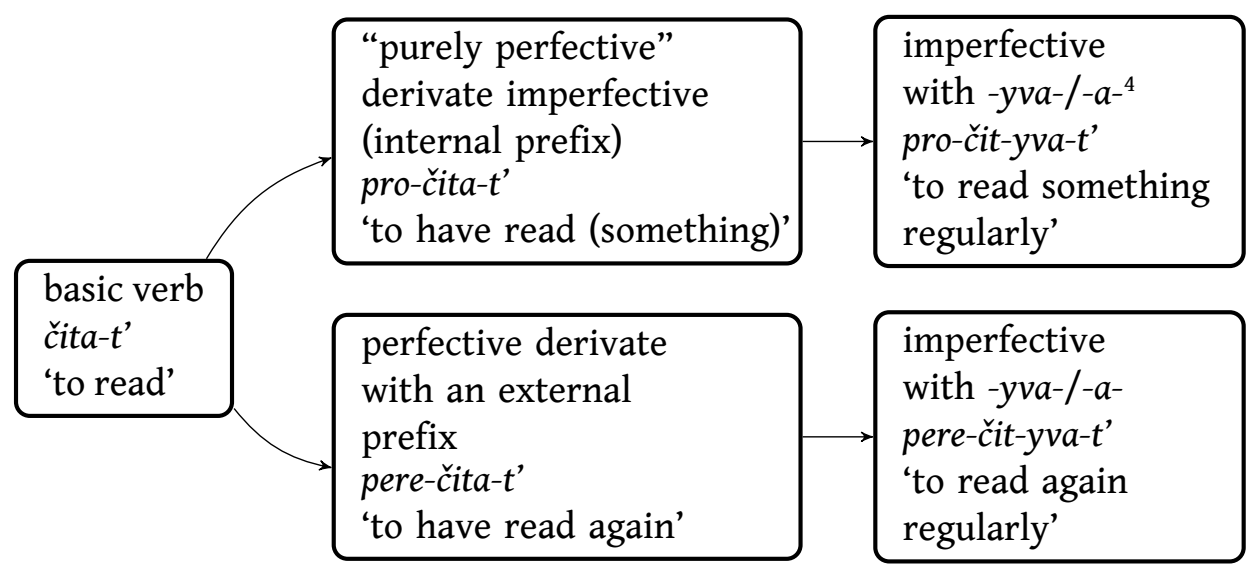

FIGURE 1: The "seeding" basic verb and its derivates.

corresponding to perfective verbal stems, 88 to imperfective stems ${ }^{3}$. Unfortunately, only 71 of these nominals had non-zero frequency in the annotated part of the Corpus, 30 "perfective", 41 "imperfective".

One can notice that imperfective stems in general nominalize more often than perfective ones (cf. 88 nominals from imperfective stems to 48 from perfective stems). However, consider the fact that out of these 88 imperfective stems only 41 (or 46,6\%) are attested in the Corpus, while for the "perfective" nominals 30 items of potentially 48 (or 75\%) are attested. The average frequencies of nominalizations of both types in the corpus (Figure 2) compared to the average frequency of the corresponding verbs (Figure 3 ) confirm this trend.

The general trend is, therefore, that imperfective stems more often have corresponding nominalizations, but nominalizations of perfective stems are averagely more frequent in the Corpus (Figure 2). Note that for the corresponding verbs the picture is quite the opposite, with imperfective verbs being more frequent (Figure 3).

Let us now switch from the binary perfective/imperfective opposition to a more fine-grained classification of verbal stems involved in the derivation of these nominals.

[3] The procedure of attributing a nominal to either a perfective or an imperfective stem is quite formal, and every nominal clearly shows which stem it belongs to. Deverbal nominals derived from perfective stems share a part of their morphology with perfective past participles in their predicative form, cf:: o-pisa- $t$ ' 'to describe' - o-pisa-N 'described' - o-pisa-N-ie 'description', otkry-t' 'to open, to discover' - otkry-t 'open, discovered' - otkry-t-ie 'opening, discovery', see Tatevosov (2003). So, if the deverbal nominal without $-i e$ is identical to a perfective past participle, which is part of the verbal paradigm and therefore clearly identifiable, this nominal corresponds to the perfective stem, otherwise to the imperfective.

[4] The nature and exact position of this a in imperfective verbs remain unclear (see discussion in Pazelskaya \& Tatevosov 2008), but for our purposes it is enough to say that it is something that makes a perfective verb an imperfective one and for many verbs it is complementarily distributed with -yva-. 


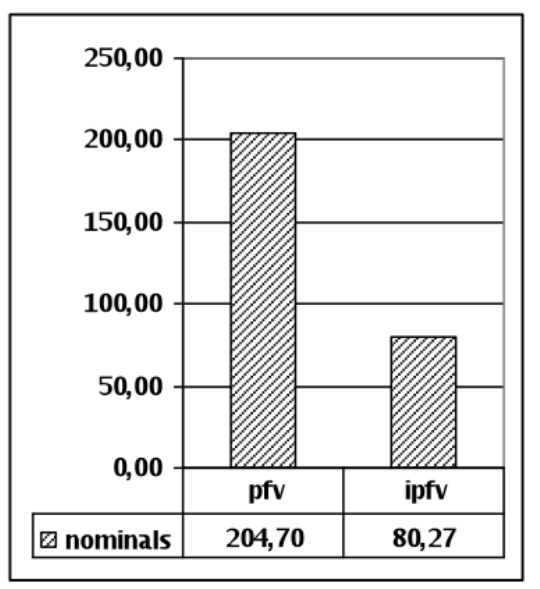

FIGURE 2: Average frequency of nominals with perfective and imperfective stems.

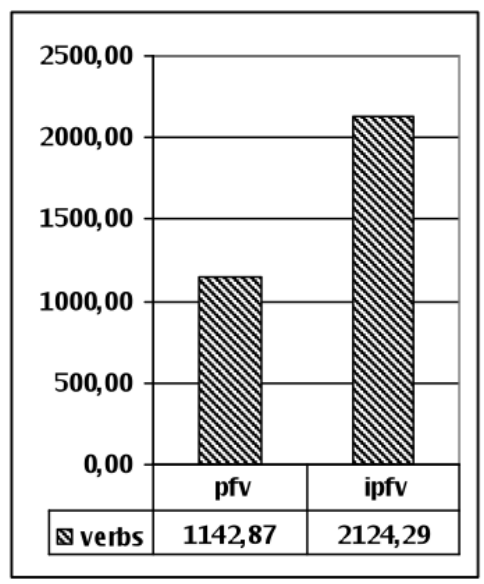

FIGURE 3: Average frequency of verbs with perfective and imperfective stems.

If we look not only at the aspectual characteristics of a verbal stem, but at the means of deriving it, namely, on the Aktionsart morphemes involved, we can recognize 5 different types of stems and therefore 5 types of nominals derived from these stems:

1. basic imperfective stems, i.e. stems giving rise to imperfective verbs and being (at least synchronically) derivationally simple: pisa-t' 'to write ${ }_{\text {IPFV }}$ ' - pisa-nie 'writing';

2. basic perfective stems, i.e. stems giving rise to perfective verbs and being (at least synchronically) derivationally simple: reši-t' 'to decide, to solve' - reše-nie 'decision, solution';

3. perfective stems with "purely perfectivizing" (in terms of Romanova 2004, 2006) prefixes, i.e. stems derived from those of type 1 by adding prefixes without their own lexical meaning: na-pisa-t ' to write $\mathrm{PFv}$ - na-pisa-nie 'writing';

4. perfective stems with all other perfectivizing prefixes, here labeled as external, these stems are also derived from stems of type 1: o-pisa-t 'to describe' o-pisa-nie 'description';

5. imperfective stems derived from perfective ones with -yva-and - $a$-, these stems can be derived from any of the stems in 2-4 by adding the imperfectivizing suffixes -yva- and -a-: o pis-yva-t' 'to describe, to be describing' - o-pis-yva-nie 'describing'. 
Figure 4 and Figure 5 show the number of nominals derived from the stems of every type in our sample (Figure 4 ), and the average frequency shown by nominals with these types of stems (Figure 5).

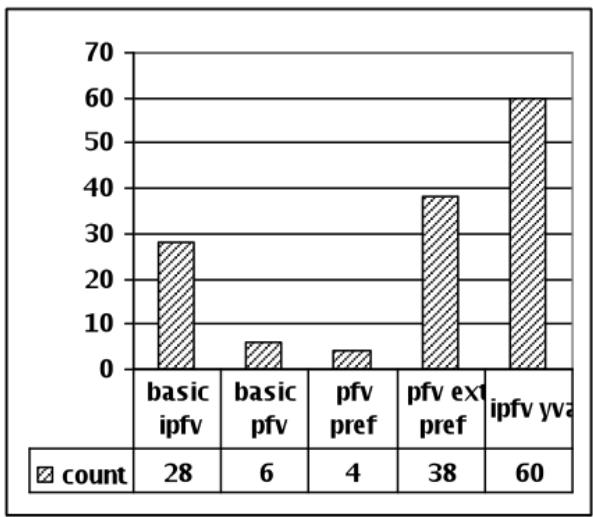

FIGURE 4: Types of stems in 136 nominals derived from the 201 most frequent verbs.

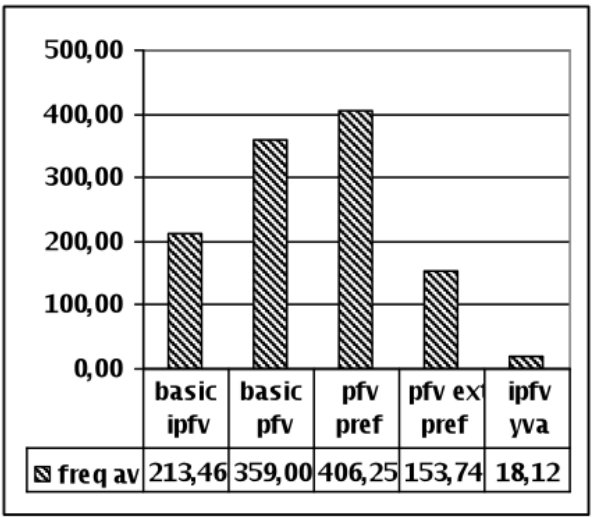

FIGURE 5: Average frequency of nominals of the 5 different types.

Figure 4 shows that imperfective stems with imperfectivizing suffixes show the highest number of derivations in our sample (60 of 136 nominals are formed from these stems), perfective stems with external prefixes are on the second place ( 38 nominals), basic imperfective stems come third ( 28 nominals), while basic perfective stems and perfective stems with purely perfectivizing prefixes derive very few nominalizations ( 6 and 4 nominals, respectively).

Figure 5 demonstrates that nominals derived from stems with purely perfectivizing stems have the maximum average frequency (i.e., the maximum number of occurrences in the Corpus); nominals from basic perfective stems are on the second place, followed by nominals corresponding to basic imperfective stems; nominalizations of perfective stems with external prefixes come next to last, while nominalizations of derived imperfective stems with imperfectivizing suffixes are the least frequent.

Note that, again, the two most productive types of stems, namely, imperfective stems with -yva- and perfective stems with "external" prefixes, derive nominals with the lowest average frequency, and, vice versa, basic perfective and prefixed perfective stems, the least productive in nominalizations, derive nominals with the highest frequency in the Corpus.

\section{[3.2] Sample 2. The most frequent nominals and what they are derived from}

Now let us turn to the second sample containing 209 -nie/tie ending nominals from the top of the frequency list, excluding non-deverbal nouns like desjatiletie 
'decade' or zdanie 'building'. Among these nominals, 152 correspond to perfective stems, 52 to imperfective, and 5 to stems which are biaspectual in their verbal form (like obeščanie 'a promise', cf. obeščat' 'to promise ${ }^{5}$ ) - the distribution is presented in Figure 6 below. Figure 7 shows the distribution of the nominals with respect to the five types of stems identified above: basic imperfective, basic perfective, prefixed perfective with purely perfectivizing prefixes, prefixed perfective with all the other ("external") prefixes, suffixed imperfective.

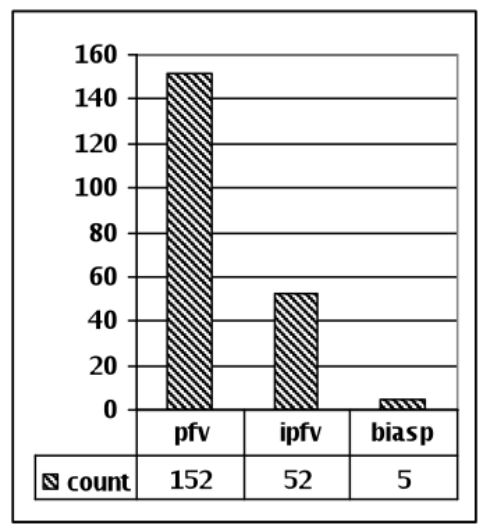

FIGURE 6: Number of -nie/tie nominals with perfective, imperfective, and biaspectual stems.

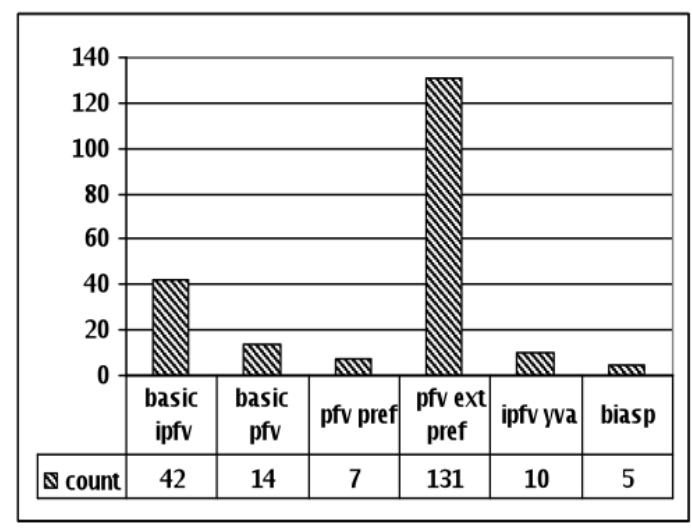

FIGURE 7: Types of stems in the 209 most frequent -nie/tie nominals.

Note that the distribution of stem types for the two samples is different (cf. the scores in Figure 7 and Figure 4). Apart from the presence of biaspectual stems with their specific morphology, Sample 2 shows crucially a low score for suffixed imperfective stems and a threefold prevalence of the number of nominals of the productive type (prefixed perfective with external prefixes) over the number of nominals of the second productive type (the ones derived from basic imperfective stems).

The average frequency scores for the nominals from the second sample of different types are given below. Figure 8 shows the average frequencies for nominals derived from all perfective stems, all imperfective stems, and biaspectual stems.

[5] See e.g. the entry for this verb in Kuznecov (1998). Biaspectual verbs, their semantics and their place in the aspectual system represent a challenge for researchers of Russian and Slavic aspect (see e.g. Anderson 2002, as well as a small state-of the-art overview in Janda 2007). What is important for us here is that their derivational structure in terms of Aktionsart morphemes is equally unclear. Therefore, in this work they will be kept apart as a separate category, different from both perfective and imperfective stems, as well as from all the five types of stems defined with respect to their derivational history. 
The average frequencies are just slightly different, imperfective nominals showing the highest score, and perfective ones the lowest.

Figure 9 presents a comparison of average frequencies for nominals corresponding to the five identified types of stems plus biaspectual stems forming a separate category. The highest score is shown by nominals corresponding to perfective stems with purely perfectivizing prefixes; average frequencies for nominalizations of both basic types of stems (perfective and imperfective) and suffixed imperfective stems are almost equal, and perfective stems with external prefixes give rise to the least frequent nominals.

The average frequency scores for most frequent nominals (Sample 2) are different from what has been attested for the nominals corresponding to the most frequent verbs in [3.1], cf. Figure 8 to Figure 2, as well as Figure 9 to Figure 5 above.

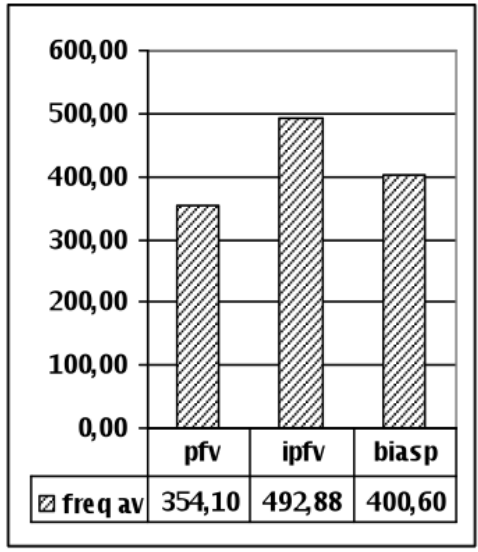

FIGURE 8: Average frequencies for -nie/tie nominals with perfective, imperfective, and biaspectual stems.



FIGURE 9: Average frequency for 209 -nie/tie nominals wrt the stem type.

Apart from the presence of several biaspectual stems, the most striking differences between the results of this sample and the results in section [3.1] are:

- higher average frequency of nominalizations of imperfective stems;

- more precisely, relatively high frequency of nominalizations of suffixed imperfective stems with -yva-.

In what follows I am going to discuss these results and propose an explanation for the attested differences. 


\begin{tabular}{|c|c|c|c|}
\hline & & Sample 1 (verb-based) & $\begin{array}{l}\text { Sample } 2 \\
\text { (nominal-based) }\end{array}$ \\
\hline 1 & $\begin{array}{l}\text { higher number of nomi- } \\
\text { nals }\end{array}$ & imperfective stems & perfective stems \\
\hline 2 & $\begin{array}{l}\text { higher number of perfec- } \\
\text { tive nominals }\end{array}$ & $\begin{array}{l}\text { nominals with external } \\
\text { prefixes }\end{array}$ & $\begin{array}{l}\text { nominals with external } \\
\text { prefixes }\end{array}$ \\
\hline 3 & $\begin{array}{l}\text { higher number of imper- } \\
\text { fective nominals }\end{array}$ & $\begin{array}{l}\text { nominals with imperfec- } \\
\text { tivizing suffixes }-y v a-/-a-\end{array}$ & $\begin{array}{l}\text { nominals derived from } \\
\text { basic imperfective stems }\end{array}$ \\
\hline 4 & higher frequency & perfective stems & imperfective stems \\
\hline 5 & $\begin{array}{l}\text { highest frequency among } \\
\text { perfective nominals }\end{array}$ & $\begin{array}{l}\text { nominals with purely } \\
\text { perfectivizing prefixes }\end{array}$ & $\begin{array}{l}\text { nominals with purely } \\
\text { perfectivizing prefixes }\end{array}$ \\
\hline 6 & $\begin{array}{l}\text { higher frequency among } \\
\text { imperfective nominals }\end{array}$ & $\begin{array}{l}\text { nominals derived from } \\
\text { basic imperfective stems }\end{array}$ & $\begin{array}{l}\text { almost equal, score of the } \\
\text { nominals derived from } \\
\text { basic imperfective stems } \\
\text { is slightly higher }\end{array}$ \\
\hline
\end{tabular}

TABLE 2: Comparison of the two samples.

\section{[4] DISCUSSION OF THE RESULTS}

The results for Sample 1 "from verb to nominalization", and Sample 2 "nominalizations as they are" are given in Table 2 .

The results in Table 2 give rise to the following generalizations:

(i) There exists a general pattern "the higher the number of nominals derived from a stem of a certain type, the less is their average frequency" (cf. lines 1 and 4 for both samples, lines 2 and 5 for both samples, lines 3 and 6 for Sample 1).

(ii) Lines 3 and 6 for Sample 2 will not be such a striking counterexample to (i) if we consider the numbers: in Sample 1 the average frequency of nominals derived from basic imperfective stems is more than ten times higher $(213,46$ vs. 18,12 ), while in Sample 2 it is only 498,05 vs. 471,2 . That is, where we would expect nominals derived from stems with -yva- to have higher frequency, it is just not so dramatically lower; therefore there should be some reason for these nominals to be less frequent than nominals derived from basic imperfective stems.

(iii) The results for the two samples are in some cases opposite: consider the number and frequency of nominals derived from perfective/imperfective stems, without details of their formation (lines 1 and 4), and the number of nominals with -yva-and the ones corresponding to basic imperfective stems (line 3). In the first sample there are more nominals derived from imperfective stems, but nominalizations of perfective stems are averagely more 
frequent, and most imperfective nominals correspond to suffixed imperfective stems. On the other hand, in the second sample nominals derived from perfective stems prevail over those derived from imperfective stems, although the latter show a higher average frequency, and among nominals derived from imperfective stems there are more of those corresponding to basic imperfective stems.

The generalization (ii) seems to be a common property of all the classes of words in a language: the bigger a natural class of words sharing some important property, the less frequent are the words the class consists of, and vice versa cf. e.g. the number and frequency of lexical and auxiliary verbs (Baayen 2001).

The reason for the lower frequency of the nominals derived from stems with -yva- (ii) might lie in their stylistic markedness. Nominalizations in Russian are generally considered as part of cold, overcomplicated, "bureaucratic" speech (cf. Nichols 1988), something which is to be avoided in e.g. creative writing (Gal' 1987). All this is in the first place true exactly for $-y v a-$ nominals, since other types of nominalizations often have the option to become more justified as result nominals (cf. the case of O-pisa-nie 'description'/?'describing' - o-pis-YVA-nie 'describing') or manner nominals (e.g. vide-t' 'to see' - vide-nie 'vision, view, viewpoint'), while -yva-nominals lack such an option. Therefore, the only role they can have is as a description of the action itself, i.e. exactly this stylistically depreciated use that other types of nominals avoid.

As for the split of results between the two samples (iii), one probable reason could be the shortage of material, especially in the first sample, and therefore it is just an incidental deviation. As far as the average frequency of perfective/ imperfective stems is considered, nominals in Sample 2 pattern together with verbs in Sample 1, and not with nominals in Sample 1. This may show, again, that the imperfective stems regain their high scores as soon as there is enough material, or, alternatively, suggest that in the higher part of the frequency distribution the profile is not the same as in the lower one. This cannot be seen without a more extensive study and more extensive samples (and, probably, more extensive annotated corpora).

This study is instructive in two main respects. First, it shows that -nie/tie nominals in their distribution with respect to aspectual characteristics of the stems they are derived from, as well as with respect to the Aktionsart morphemes in them, respect the statistical law "the bigger class - less frequent items". Second, the study confirms the general view of those of -nie/tie nominals which have the only option of denoting a situation, as generally potential, but rarely attested in the real life type of words (Nichols 1988), that is, as something more like a syntactic construction than part of the lexicon. 
[5] GLOSSES

In examples (1-8) and throughout the text the following glosses are used:

\begin{tabular}{llll}
\hline PST & past tense & INF & infinitive \\
PREF & prefix & NMN & nominalizer \\
DELIM & delimitative prefix & PL & plural number \\
CUMUL & cumulative prefix & GEN & genitive case \\
YVA & imperfectivizing suffix & INSTR & instrumental case \\
REFL & verbal reflexive marker & & \\
\hline
\end{tabular}

\section{ACKNOWLEDGEMENTS}

I would like to thank Sergei Tatevosov for sharing his work on verbal prefixes and their relation to aspect in Russian, as well as for fruitful discussions of the related issues. My thanks also go to all the people involved in creating and maintaining the Russian National Corpus, especially to Dmitry Sichinava who gave me the frequency lists of words in the annotated part of the Russian National Corpus. Finally, I want to thank the audience of the Russian Verb conference for their valuable comments, especially Peter Arkadiev, Stephen Dickey, Dmitry Gerasimov, and Laura Janda.

All the errors, omissions and other shortcomings of this paper are of course mine.

\section{REFERENCES}

Alexiadou, Artemis. 2001. Functional Structure in Nominals. Amsterdam: Benjamins.

Anderson, Cori. 2002. Biaspectual Verbs and Their Implications for the Category of Aspect in Russian: The University of North Carolina Senior Honor dissertation.

Baayen, R. Harald. 2001. Word Frequency Distributions. Dordrecht: Kluwer.

Babko-Malaya, Olga. 1999. Zero Morphology: A Study of Aspect, Argument Structure and Case. New Jersey: The State University of New Jersey, Ph.D. dissertation.

Borik, Olga. 2006. Aspect and reference time. Oxford: Oxford University Press.

Brinton, Laurel J. 1995. The aktionsart of deverbal nouns in English. In P. M. Bertinetto, V. Bianchi, Ö. Dahl \& M. Squartini (eds.), Temporal Reference, Aspect, and Actionality, 27-42. Torino.

Comrie, Bernard. 1980. Nominalization in Russian: lexical noun phrases or transformed sentences? In C. V. Chvany \& R. D. Brecht (eds.), Morphosyntax in Slavic, 212-220. Ohio: Columbus. 
Dickey, Stephen M. 2000. Parameters of Slavic Aspect. A Cognitive Approach. Stanford: CSLI Publications.

Filip, Hana. 1999. Aspect, eventuality types and noun phrase semantics. New York, London: Garland Publishing.

Filip, Hana. 2005a. On accumulating and having it all. In H. Verkuyl, H. de Swart \& A. van Hout (eds.), Perspectives on Aspect, 125-148. Dordrecht: Springer.

Filip, Hana. 2005b. The Telicity Parameter Revisited. In Semantics and Linguistic Theory (SALT) XIV, Ithaca, NY: CLC Publications.

Forsyth, James. 1970. Grammar of Aspect. Usage and meaning in the Russian Verb. Cambridge: Cambridge University Press.

Gal', N.Ya. 1987. Slovo živoe i mërtvoe. Iz opyta perevodčika i redaktora (Live word and dead word. From my experience as editor and translator). 4 th revised edition. Moscow: Cambridge University Press.

Grimshaw, Jane. 1990. Argument Structure. Cambridge: MIT Press.

Ivannikova, E. A. 1972. K voprosu ob aspekte izučenia kategorii vida u otglagol'nyx suščestvitel'nyx v russkom jazyke (Towards studying the category of verbal aspect of deverbal nominals in Russian). Izvestija AN SSSR, Literature \& Language series 31(2). 113-123.

Janda, Laura A. 2007. What makes Russian Bi-aspectual verbs Special. In D. Divjak \& A. Kochanska (eds.), Cognitive Paths into the Slavic Domain. Cognitive Linguistics Research, 83-109. Berlin and New York: Mouton de Gruyter.

Kuznecov, S. A. (ed.). 1998. Bol'šoj tolkovyj slovar' russkogo yazyka (Big Explanatory Dictionary of Russian). Saint-Petersburg: Norint.

Martin, Fabienne. 2008. The Semantics of Eventive Suffixes in French, vol. 1, Stuttgart: University of Stuttgart.

Nichols, Johanna. 1988. Nominalization and assertion in scientific Russian prose. In John Haiman \& Sandra A. Thompson (eds.), Clause Combining in Grammar and Discourse, 349-428. Amsterdam: Philadelphia: John Benjamins.

Padučeva, E.V. 1974. O semantike sinkaksisa (About syntax semantics). Moscow: Nauka.

Pazelskaya, A. G. 2009a. Modeli derivatsii i sintaksičeskaja pozitsija otglagol'nyx suščestvitel'nyx po korpusnym dannym (Derivational models and syntactic position of deverbal nominals on corpus data), vol. 8 (15), 373-378. Moscow. 
Pazelskaya, A. G. 2009b. Modeli derivatsii otglagol'nyx suščestvitel'nyx: vglyad iz korpusa (Derivational models of deverbal nominals on corpus data). In E.V. Rakhilina S.G. Tatevosov K.L. Kisseleva, V.A. Plungyan (ed.), Korpusnye issledovaniya po russkoj grammatike (Corpus studies of Russian grammar), 65-91. Moscow: Probel.

Pazelskaya, A. G. \& Sergei G. Tatevosov. 2008. Отглагольное имя и структура русского глагола (Deverbal nominal and the structure of Russian verb). In S. G. Tatevosov V. A. Plungyan (ed.), Исследования по глагольной деривации (Investigations of verbal derivation), 348-379. Moscow: Jazyki slavjanskix kultur.

Pazelskaya, Anna G. \& Sergei G. Tatevosov. 2006. Uninflected VPs, Deverbal Nouns and the Aspectual Architecture of Russian. In J.E. Lavine, S. Franks, M. TassevaKurktchieva \& H. Filip (eds.), Formal Approaches to Slavic Linguistics 14. The Princeton Meeting, 258-276. Ann Arbor: Michigan Slavic Publicatoins.

Peshkovsky, A. M. 1956. Russkij sintaksis v naučnom osveř̌čnii (Russian syntax in scientific persective. Moscow: Nauka.

Ramchand, G. 2004. Time and the event: The semantics of Russian prefixes. Nordlyd. Special issue on Slavic prefixes 32(2).

Romanova, E. 2004. Superlexical vs. lexical prefixes. Nordlyd. Special issue on Slavic prefixes $32(2)$.

Romanova, E. 2006. Constructing Perfectivity in Russian: Ph.D. dissertation. University of Tromso dissertation.

Tatevosov, Sergei G. 2009. Perfectivity Dilemma: Verbless Aspect and Aspectless Verb.

Tatevosov, Sergei G. Anna G. Pazelskaya. 2003. Nominalization in Russian: eventuality types and aspectual properties. In Paul Robert van Rooy Dekker (ed.), Proceedings of the 14th Amsterdam Colloquium, 169-174. Amsterdam: Amsterdam University.

Zaliznjak, Anna \& Alexey Shmelev. 2000. Vvedenie v russkuju aspektologiju (Introduction to Russian aspectology). Moscow: Nauka.

AUTHOR CONTACT INFORMATION

Anna Pazelskaya

proezd Shokalskogo, 18 'b', 162

Moscow

Russia

avis39@mail.ru 